\title{
Front Matter: Volume 9084
}

, "Front Matter: Volume 9084," Proc. SPIE 9084, Unmanned Systems Technology XVI, 908401 (24 June 2014); doi: 10.1117/12.2073310

SPIE. Event: SPIE Defense + Security, 2014, Baltimore, MD, United States 


\title{
PROCEEDINGS OF SPIE
}

\section{Unmanned Systems Technology XVI}

Robert E. Karlsen

Douglas W. Gage

Charles M. Shoemaker

Grant R. Gerhart

Editors

\author{
6-8 May 2014 \\ Baltimore, Maryland, United States
}

Sponsored and Published by

SPIE 
The papers included in this volume were part of the technical conference cited on the cover and title page. Papers were selected and subject to review by the editors and conference program committee. Some conference presentations may not be available for publication. The papers published in these proceedings reflect the work and thoughts of the authors and are published herein as submitted. The publisher is not responsible for the validity of the information or for any outcomes resulting from reliance thereon.

Please use the following format to cite material from this book:

Author(s), "Title of Paper," in Unmanned Systems Technology XVI, edited by Robert E. Karlsen, Douglas W. Gage, Charles M. Shoemaker, Grant R. Gerhart, Proceedings of SPIE Vol. 9084 (SPIE, Bellingham, WA, 2014) Article CID Number.

ISSN: 0277-786X

ISBN: 9781628410211

Published by

SPIE

P.O. Box 10, Bellingham, Washington 98227-0010 USA

Telephone +1 3606763290 (Pacific Time) · Fax +1 3606471445

SPIE.org

Copyright @ 2014, Society of Photo-Optical Instrumentation Engineers.

Copying of material in this book for internal or personal use, or for the internal or personal use of specific clients, beyond the fair use provisions granted by the U.S. Copyright Law is authorized by SPIE subject to payment of copying fees. The Transactional Reporting Service base fee for this volume is $\$ 18.00$ per article (or portion thereof), which should be paid directly to the Copyright Clearance Center (CCC), 222 Rosewood Drive, Danvers, MA 01923. Payment may also be made electronically through CCC Online at copyright.com. Other copying for republication, resale, advertising or promotion, or any form of systematic or multiple reproduction of any material in this book is prohibited except with permission in writing from the publisher. The CCC fee code is 0277-786X/14/\$18.00.

Printed in the United States of America.

Publication of record for individual papers is online in the SPIE Digital Library.

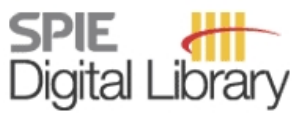

SPIEDigitalLibrary.org

Paper Numbering: Proceedings of SPIE follow an e-First publication model, with papers published first online and then in print and on CD-ROM. Papers are published as they are submitted and meet publication criteria. A unique, consistent, permanent citation identifier (CID) number is assigned to each article at the time of the first publication. Utilization of CIDs allows articles to be fully citable as soon as they are published online, and connects the same identifier to all online, print, and electronic versions of the publication. SPIE uses a six-digit CID article numbering system in which:

- The first four digits correspond to the SPIE volume number.

- The last two digits indicate publication order within the volume using a Base 36 numbering

system employing both numerals and letters. These two-number sets start with 00, 01, 02, 03, 04, 05, 06, 07, 08, 09, 0A, 0B ... 0Z, followed by 10-1Z, 20-2Z, etc.

The CID Number appears on each page of the manuscript. The complete citation is used on the first page, and an abbreviated version on subsequent pages. Numbers in the index correspond to the last two digits of the six-digit CID Number. 


\section{Contents}

vii Conference Committee
ix Introduction

\section{SPECIAL TOPICS}

$908402 \quad$ Neurobiomimetic constructs for intelligent unmanned systems and robotics [9084-1] J. J. Braun, D. C. Shah, M. A. DeAngelus, MIT Lincoln Lab. (United States)

908403 Intermittent communications modeling and simulation for autonomous unmanned maritime vehicles using an integrated APM and FSMC framework [9084-2]

A. Coker, L. Straatemeier, T. Rogers, Space and Naval Warfare Systems Ctr. Pacific (United States); P. Valdez, K. Griendling, D. Cooksey, Georgia Institute of Technology (United States)

908405 Automating software design and configuration for a small spacecraft [9084-4] J. Straub, The Univ. of North Dakota (United States)

908406 Modeling and simulation of an unmanned ground vehicle power system [9084-5] J. Broderick, Univ. of Michigan (United States); J. Hartner, U.S. Army Tank Automotive Research, Development and Engineering Ctr. (United States); D. Tilbury, E. Atkins, Univ. of Michigan (United States)

908408 Autonomous self-righting using recursive Bayesian estimation to determine unknown ground angles [9084-8]

J. Collins, Engility Corp. (United States); C. Kessens, U.S. Army Research Lab. (United States)

908409 Multi-arm multilateral haptics-based immersive tele-robotic system (HITS) for improvised explosive device disposal [9084-9]

D. Erickson, Defence Research and Development Canada, Suffield (Canada);

H. Lacheray, G. Lai, A. Haddadi, Quanser Consulting Inc. (Canada)

9084 OB Speech and gesture interfaces for squad-level human-robot teaming [9084-11]

J. Harris, D. Barber, Univ. of Central Florida (United States)

9084 OC New generation of human machine interfaces for controlling UAV through depth-based gesture recognition [9084-12]

T. Mantecón, C. R. del Blanco, F. Jaureguizar, N. García, Univ. Politécnica de Madrid (Spain)

RCTA

9084 OD Supporting task-oriented collaboration in human-robot teams using semantic-based path planning [9084-13]

D. Yi, M. A. Goodrich, Brigham Young Univ. (United States) 
9084 OE Determinants of system transparency and its influence on trust in and reliance on unmanned robotic systems [9084-14]

S. Ososky, T. Sanders, F. Jentsch, P. Hancock, Univ. of Central Florida (United States);

J. Y. C. Chen, U.S. Army Research Lab. (United States)

9084 OF An interdisciplinary taxonomy of social cues and signals in the service of engineering robotic social intelligence [9084-15]

T. J. Wiltshire, E. J. C. Lobato, J. Velez, F. G. Jentsch, S. M. Fiore, Univ. of Central Florida (United States)

9084 OG Validation and verification of a high-fidelity computational model for a bounding robot's parallel actuated elastic spine [9084-16]

J. L. Pusey, J.-H. Yoo, U.S. Army Research Lab. (United States)

$9084 \mathrm{OH} \quad$ Temporally consistent segmentation of point clouds [9084-18]

J. L. Owens, U.S. Army Research Lab. (United States); P. R. Osteen, Engility Corp.

(United States); K. Daniilidis, Univ. of Pennsylvania (United States)

$90840 \mathrm{Ol} \quad$ Common world model for unmanned systems: Phase 2 [9084-19]

R. M. S. Dean, General Dynamics Land Systems (United States); J. Oh, National Robotics

Engineering Ctr. (United States); J. Vinokurov, Carnegie Mellon Univ. (United States)

$90840 \mathrm{~J}$ Integration and demonstration of MEMS-scanned LADAR for robotic navigation [9084-20]

B. L. Stann, J. F. Dammann, U.S. Army Research Lab. (United States); M. Del Giorno, Del

Services LLC (United States); C. DiBerardino, General Dynamics Robotic Systems (United States); M. M. Giza, U.S. Army Research Lab. (United States); M. A. Powers, General

Dynamics Robotic Systems (United States); N. Uzunovic, Robotic Research LLC (United States)

9084 OK Head-orientation for a sidewinding snake robot using modal decomposition [9084-21]

E. A. Cappo, M. Travers, H. Choset, Carnegie Mellon Univ. (United States)

9084 OL Tip-over prevention through heuristic reactive behaviors for unmanned ground vehicles [9084-7]

K. Talke, L. Kelley, P. Longhini, G. Catron, Space and Naval Warfare Systems Ctr. Pacific (United States)

\section{MOBILITY AND NAVIGATION}

9084 OM Object guided autonomous exploration for mobile robots in indoor environments [9084-22] C. Nieto-Granda, S. Choudhary, Georgia Institute of Technology (United States);

J. G. Rogers III, J. Twigg, U.S. Army Research Lab. (United States); V. Murali, H. I. Christensen, Georgia Institute of Technology (United States)

9084 ON Development and evaluation of the Stingray, an amphibious maritime interdiction operations unmanned ground vehicle [9084-23]

H. G. Nguyen, Space and Naval Warfare Systems Ctr. Pacific (United States); C. R. Castelli, Macro USA Corp. (United States) 
908400 Micro air vehicle autonomous obstacle avoidance from stereo-vision [9084-24]

R. Brockers, Y. Kuwata, S. Weiss, L. Matthies, Jet Propulsion Lab. (United States)

9084 OP Assisted autonomy of articulated snake robots [9084-25]

D. Rollinson, H. Choset, Carnegie Mellon Univ. (United States)

$9084 \mathrm{OQ}$ Counter tunnel exploration, mapping, and localization with an unmanned ground vehicle [9084-26]

J. Larson, B. Okorn, T. Pastore, D. Hooper, J. Edwards, Space and Naval Warfare Systems Ctr. Pacific (United States)

9084 OR On the consistency analysis of A-SLAM for UAV navigation [9084-27]

A. E. Oguz, Turkish Air Force Academy (Turkey); H. Temeltas, Istanbul Technical Univ. (Turkey)

\section{PERCEPTION}

9084 OS Infrared stereo calibration for unmanned ground vehicle navigation [9084-29]

J. Harguess, Space and Naval Warfare Systems Ctr. Pacific (United States); S. Strange,

Leidos, Inc. (United States)

9084 OT A robust method for online stereo camera self-calibration in unmanned vehicle system [9084-30]

Y. Zhao, N. Chihara, T. Guo, N. Kimura, Hitachi, Ltd. (Japan)

9084 OU Investigating clutter reduction for unmanned systems applications using imaging polarimetry [9084-31]

J. B. Hanks, T. M. Aycock, D. B. Chenault, Polaris Sensor Technologies, Inc. (United States)

9084 OV Absolute localization of ground robots by matching LiDAR and image data in dense forested environments [9084-32]

M. Hussein, Massachusetts Institute of Technology (United States); M. Renner, U.S. Army Engineer Research and Development Ctr. (United States); K. Iagnemma, Massachusetts Institute of Technology (United States)

9084 OW Occluded human recognition for a leader following system using 3D range and image data in forest environment [9084-33]

K. Cho, M. Ilyas, Univ. of Science \& Technology (Korea, Republic of); S.-H. Baeg, S. Park,

Korea Institute of Industrial Technology (Korea, Republic of)

POSTER SESSION

9084 OY A practical approach to considering uncertainties in the creation of autonomous behaviors in unmanned surface vehicles [9084-35]

Z. J. Bay, DSO National Labs. (Singapore); C. W. Yew, Tigerlab Pte Ltd. (Singapore); A. Yue,

Y. F. Lee, A. P. New, H. Y. Gan, DSO National Labs. (Singapore) 
$90840 Z$ HALOS: fast compact autonomous adaptive optics for UAVs [9084-36]

G. Andersen, P. Gelsinger-Austin, F. Ghebremichael, P. Gaddipati, R. Gaddipati, HUA, Inc. (United States)

908410 Use of eternal flight unmanned aircraft in military operations [9084-37]

Z. Kök, Turkish Air War College (Turkey)

$908411 \quad$ Roll angle measurement using a polarization scanning reference source [9084-38]

H. S. Dhadwal, J. Rastegar, V. Kankipati, Omnitek Partners, LLC (United States)

908413 Controlling UCAVs by JTACs in CAS missions [9084-40]

A. E. Kumaş, Turkish Air War College (Turkey)

908416 Current and future possibilities of V2V and I2V technologies: an analysis directed toward Augmented Reality systems [9084-45]

J. A. Betancur, G. Osorio-Gómez, A. Arnedo, A. Yarce Botero, Univ. EAFIT (Colombia)

908417 A $10 \mathrm{GHz}$ polarization scanning reference source [9084-46]

H. S. Dhadwal, J. Rastegar, Omnitek Partners, LLC (United States)

Author Index 


\section{Conference Committee}

Symposium Chair

David A. Whelan, Boeing Defense, Space, and Security

(United States)

Symposium Co-chair

Nils R. Sandell Jr., Strategic Technology Office, DARPA (United States)

Conference Chairs

Robert E. Karlsen, U.S. Army Tank Automotive Research, Development and Engineering Center (United States)

Douglas W. Gage, XPM Technologies (United States)

Charles M. Shoemaker, U.S. Army Communications-Electronics Research Development and Engineering Command (United States)

Grant R. Gerhart, U.S. Army Tank-Automotive Research,

Development, and Engineering Ctr.-Retired (United States)

Conference Program Committee

Jonathan A. Bornstein, U.S. Army Research Laboratory (United States) Jared Giesbrecht, Defence Research and Development Canada, Suffield (Canada)

Frank L. Lewis, The University of Texas at Arlington (United States)

Larry H. Matthies, Jet Propulsion Laboratory (United States)

Camille S. Monnier, Charles River Analytics, Inc. (United States)

Paul L. Muench, U.S. Army Tank Automotive Research, Development and Engineering Center (United States)

Hoa G. Nguyen, Space and Naval Warfare Systems Center Pacific (United States)

James L. Overholt, Air Force Research Laboratory (United States)

Mike Perschbacher, RovnoTech (United States)

Marc Raibert, Boston Dynamics (United States)

Klaus-Juergen Schilling, Julius-Maximilians-Universität Würzburg (Germany)

Anthony Stentz, Carnegie Mellon University (United States)

Gary Witus, Turing Associates, Inc. (United States)

Brian M. Yamauchi, iRobot Corporation (United States) 


\section{Session Chairs}

Special Topics

Douglas W. Gage, XPM Technologies (United States)

Charles M. Shoemaker, U.S. Army Communications-Electronics Research Development and Engineering Command (United States)

Keynote Session: Joint Session with Conference 9096

Robert E. Karlsen, U.S. Army Tank Automotive Research, Development and Engineering Center (United States)

RCTA

Jonathan A. Bornstein, U.S. Army Research Laboratory (United States)

Mobility and Navigation

Hoa G. Nguyen, Space and Naval Warfare Systems Center Pacific (United States)

Roland Brockers, Jet Propulsion Laboratory (United States)

Perception

Camille S. Monnier, Charles River Analytics, Inc. (United States)

Paul L. Muench, U.S. Army Tank Automotive Research, Development and Engineering Center (United States) 


\section{Introduction}

The Unmanned Systems Technology XVI Conference consisted of seven sessions that spanned nearly three days and covered a variety of areas within robotics. Although the vast majority of fielded unmanned systems are teleoperated, especially for ground systems, the push for autonomy is increasing due to the public perception that it is within our grasp, due to commercial endeavors at the automotive companies and at Google. This year's conference also shows that, while there is still interest in the standard unmanned technologies, there is also interest in other forms of robotics, such as micro air vehicles, which are becoming rather ubiquitous in terms of commercial availability, as well as the machine intelligence that robots will require to operate closely with humans.

The opening session on Tuesday afternoon was devoted to the always interesting Special Topics session, which this year began with a paper on neurobiomimetic cognitive architectures. This was followed by papers on communications modeling, controls for a small satellite, and power usage modeling for small unmanned ground vehicles. Manipulation was the subject of two papers, including self-righting and the use of immersive displays, followed by papers on using speech and gestures to communicate with unmanned systems. HumanRobot Interactions (HRI) is important for integrating robots into a squad or for managing a distant team of unmanned vehicles, and will require methods beyond the current laptop and joystick, especially for complex manipulation tasks.

The conference's poster session took place on Tuesday night with papers on autonomy for unmanned surface vessels, optics and solar power for unmanned air vehicles (UAV), vehicle-to-vehicle and infrastructure-to-vehicle communication, military use of UAV's, and methods for using polarization to determine vehicle orientation.

Wednesday began with a session on open architectures, which was joint with Conference 9096, Open Architecture/Open Business Model Net-Centric Systems and Defense Transformation 2014. Since robotics is a relatively new industry, it currently struggles with issues of interoperability and lacks widespread open standards. This session consisted of four keynotes and a panel discussion on this important issue that needs to be addressed before wide-spread production and utilization of unmanned systems will be feasible.

The Wednesday afternoon session had papers from the Army Research Laboratory's (ARL) Robotics Collaborative Technology Allance (CTA), which is performing research perception, intelligence, HRI, and mobility and manipulation to enable squad-level robot team members. The papers described current research on shared mental models, trust and social cues in HRI, flexible spine 
modeling for a four-legged robot and head control for snake robots, ladar development and point cloud processing, and building common world models.

Thursday morning brought a joint session with Conference 9083, Micro- and Nanotechnology Sensors, Systems, and Applications VI, and consisted of work performed under ARL's Micro-Autonomous Systems and Technology (MAST) CTA. The papers described modeling and characterization of flapping wing and quadrotor air vehicles, as well as autonomous energy charging and power management, storage, and component development and integration. The technologies for these micro-sized platforms often require paradigm shifts, since many standard unmanned technologies do not scale well with size.

Thursday afternoon led off with the Mobility and Navigation session with papers on navigation for unmanned ground, surface and air vehicles, as well as for snake robots and for tunnel exploration. This was followed by the Perception session that looked at infrared and visual stereovision calibration, infrared polarimetry, and localization and navigation through forests.

This year's conference covered a wide swath of unmanned systems technologies and demonstrates why robotics is such an exciting area. We want to especially thank those that stepped forward and assisted in making this a successful conference in spite of the issues with government funding and conference attendance regulations. We hope you enjoy these proceedings and are able to attend the conference next year.

\section{Robert E. Karlsen Douglas W. Gage Charles M. Shoemaker Grant R. Gerhart}

